\title{
Turkish-Ottoman relations with Latin America: a journey through the time capsule
}

\section{Las relaciones turco-otomanas con América Latina: un recorrido a través de las cápsulas del tiempo}

* PHD in International Relations. Deputy Director of the Rosary Institute in Arab and Islamic World Studies (IREMAI) and coordinator of the Middle East Studies Group (GEMO) of the Faculty of Political Science and International Relations

of the National University of Rosario (UNR), Argentina

\section{Relações turco-otomanas com a América Latina: uma viagem pelas cápsulas do tempo}

\author{
Rubén Paredes Rodríguez*
}

DOI: 10.5752/P.2317-773X.2020v8.n4.p188

Received in: September 21, 2020

Accepted in: January 29, 2021

\begin{abstract}
In this article we propose to address the opening of three Time Capsules to reconstruct three clearly identifiable contexts, each providing information for the analysis of what international relations between the Ottoman Empire/Turkey with Latin America have been like. In this way, we seek to analyze the content of the links through the density of the macro-relationships that developed over time, in order to make a cognitive map of the state of situation, taking into account not only the interests of the actors but also the endogenous and exogenous conditions. In that line are raised three contexts of opening the Capsules of Time. The first in 1923, when the Empire died and the Republic of Turkey was born; the second at the end of the 20th century; and the third in 2019, spanning almost the first two decades of the 21 st century.
\end{abstract}

Keywords: Ottoman Empire. Turkey. Relations. Latin America.

\section{RESUMEN}

En el presente artículo proponemos abordar la apertura de tres Capsulas del Tiempo para reconstruir tres contextos claramente identificables, cada uno de ellos brindando información para el análisis de cómo han sido las relaciones internacionales entre el Imperio Otomano/Turquía con América Latina. De ese modo, buscamos analizar el contenido de los vínculos a través de la densidad de las macro-relaciones que se desarrollaron en el tiempo, con el fin de realizar un mapa cognitivo del estado de situación, atendiendo no solo a los intereses de los actores sino también a los condicionantes endógenos y exógenos. En esa línea se plantean tres contextos de apertura de las Capsulas del Tiempo. El primero en 1923, cuando muere el Imperio y nace la República de Turquía; el segundo a fines del siglo XX; y el tercero en 2019, abarcando casi las dos primeras décadas del siglo XXI.

Palabras clave: Imperio Otomano. Turquía. Relaciones. América Latina. 


\section{RESUMO}

Neste artigo propomos abordar a abertura de três Cápsulas do Tempo para reconstruir três contextos claramente identificáveis, cada um fornecendo informações para a análise de como têm sido as relações internacionais entre o Império Otomano/Turquia com a América Latina. Dessa forma, buscamos analisar o conteúdo dos elos através da densidade das macro-relações que se desenvolveram ao longo do tempo, a fim de fazer um mapa cognitivo do estado de situação, levando em conta não apenas os interesses dos atores, mas também as condições endógenas e exógenas. Nessa linha são levantados três contextos de abertura das Cápsulas do Tempo. A primeira em 1923, quando o Império morreu e a República da Turquia nasceu; o segundo no final do século XX; e a terceira em 2019, abrangendo quase as duas primeiras décadas do século XXI.

Palavras-chave: Império Otomano. Turquia. Relações. América Latina.

Introduction

In the 21 st century there was a strong interest in diversifying and deepening external relations between the Republic of Turkey and Latin America through several specific initiatives. However, the links between the two actors are not recent and can be studied in line with different regional and international contexts over time.

Precisely, to understand what the international relations between the two actors have been, we propose to make a novel approach, not far from the current reality that we have to live, where streaming has changed the way we consume audiovisual services, among other issues the popular TV series. In this sense, a three-season lag can be raised to analyze from a perspective of International Relations what the link between two actors from distant regions that make up the international system has been like. On the one hand, the then Ottoman Empire (later Republic of Turkey) and on the other, the region of Latin America.

The script that is proposed for each of the seasons is the opening of three Time Capsules - recalling the Westinghouse idea - that were buried with the idea of them opening at a certain date and thus providing knowledge about the historical context analyzed. The Time Capsules were created by Westinghouse and were presented at the World Exhibition of New York as part of their exhibition. The first measured 2.28 meters, weighed $363 \mathrm{~kg}$, and had an inner diameter of 16 centimeters with a nickel and silver alloy, harder than steel. At first it was sought to bury them with the aim that they are open in the future, but given the development of the technology, they were also placed in space. Inside, varied articles such as books, diverse objects and brochures were kept that were intended to provide knowledge to all of humanity about a context of history when they were opened.

In this article we propose to address the opening of three Time Capsules to reconstruct three clearly identifiable contexts, each providing information and tools for the analysis of what international relations between the Ottoman Empire/Turkey have been like with Latin America. In this way, we seek to analyze the content of the links through the density of the macro-relationships that developed over time, in order to make 
a cognitive map of the state of situation, taking into account not only the interests of the actors but also the endogenous and exogenous conditions. According to Carlos Escudé, from a theoretical-methodological perspective, the global macro-relationship comprises the broad political framework on which a bilateral relationship is based and translates into expressions and actions of governments in the political-diplomatic dimension that make it possible to move forward on micro-relations. The dimension of the global macro-relationship is the one that sets - to a greater extent the rules of the game of linkage. For their part, micro-relations are articulated around a plurality of specific problems which oversee a multiplicity of individual, public, and private actors - state agencies, the business sectorial and investment groups (ESCUDÉ, 1991). In this work, we will focus on the content of macro-relations between Turkey and Latin America. In this line, three contexts of opening the capsules of time are raised. The first in 1923, when the Empire died and the Republic of Turkey was born; the second at the end of the 20th century; and the third in 2019, spanning almost the first two decades of the 21 st century.

\section{The Ottoman Empire's ties to Latin America until 1923}

With the opening of the first capsule in 1923, we can understand what the path of international relations between the Ottoman Empire and Latin America was like in the context, events, and interests of these actors. That is why it is important to start with the influence of exogenous conditions.

The Ottoman Empire had about 600 years of life and expanded throughout the Middle East and North Africa (MENA), reaching to the gates of Austria in 1683, passing before the Balkans, and reaching the borders of Crimea. As Turk rightly argues: "The Turkish people played a very important role in the history of mankind because it formed 16 great empires such as the Huns, the Heavenly Turks, Ottoman Selyuquis and finally the Turkish Republic" (TURK, 2010, p. 2). But above all, the West's contact with the East through the Ottoman Empire redefined the borders of the long-known world, with the construction of identities in relational terms, emphasizing otherness (i.e. Christian Europe versus Islamic Ottoman imperial political unity).

For this reason, the importance of the latter as a reference point cannot be overlooked, since the "Turkish" has been present in the change of eras that marked the development of universal history. That is to say, "The Turks have opened and closed eras, with the fall of the Western Roman Empire in the 5th century by the Huns (Ancient Age) and with the fall of the Byzantine Empire in the fifteenth century by the Ottomans (Middle Ages). Anatolia, present-day Turkey, is arguably the cradle of Eastern and Western civilization, which for centuries inhabited that land and left their legacies, footprints and teachings for humanity" (TURK, 2010, p. 2).

It is worth mentioning that Madrid and Istanbul, both heads of vast empires that contested the dominance of the Mediterranean in the sixteenth century, ignored each other in the last centuries (VALLEJO 
FERNÁNDEZ CELA, 2010). Only at the end of the eighteenth century, both empires will have a rapprochement, coinciding with the twilight of one and the decay of the other. The signing of the Treaty of Peace, Friendship and Trade between Spain and the Ottoman Empire of 14 September 1782, sealed by King Charles III and Sultan Abd-lhami I (1774-1789) ended more than two centuries of hostilities (VALLEJO FERNÁNDEZ CELA, 2001, p. 20). Until then, the contacts were non-existent. This explains why there was no "strong orientalist current in Spain" compared to France and Britain whose interests were in reaching a portion of territory of the vast Ottoman Empire.

This situation gave account of an atmospheric imperialism, where another active actor was added in the international reconfiguration as was the Empire of the Tsars, with territorial pretensions over the Ottoman Empire. However, it should not be overlooked that with the beginning of the renaissance and religious reform in Europe, together with the new technologies that allowed invention and innovation in the development of capitalism, coupled with the system of post-Congress power of Vienna of 1815, were gradually affecting the Ottoman State. This process intensified in the 19th century, forcing the Ottomans to make several attempts at reforms known as Tanzimat in the political, economic, and military dimensions- to introduce Modernity and modernization into the empire.

Despite this, the secret diplomacy, and interests of much of the powers of the pentarchy were conditioning the future of the Ottoman Empire with territorial losses, which were exacerbated by World War I. At the time, the so-called "sick man of Europe" was a euphemism that made him part of a continent that saw him not as his own but as a stranger, another threatening and agonizing of the virus of European fever intended to distribute the territories.

World War I had a devastating effect on the Ottoman Empire. This produced a significant geopolitical design where the problems that exist today in the MENA region have their origin, precisely, in the decisions made by the winning powers.

As Mehmet Necati Kutlu rightly submits, "in this geopolitical context of dispute over the Ottoman territory the tactic of fragmentation of many peoples was applied, where separatism and segregation were encouraged from the outside" (EQUILIBRIUM GLOBAL, 2018).

For this reason, the disintegration of the Ottoman Empire throughout the 19th century is marked by several stages, in which reformist attempts by sultans and rulers are preceded by increasing European penetration in all areas. The culmination of the latter was the secret Sykes-Picot agreement sealing the fate of the Ottoman Empire as a multi-ethnic and multinational unit and which started the path towards the formation of the Republic of Turkey.

In this context, endogenous conditions have also been present. In the nineteenth century, Latin America undertook the process of decolonization of the Spanish Bourbon crown in 1810, with the May Revolution of the Viceroyalty of the Río de la Plata generating a contagion effect on the captaincy of Chile and Venezuela but also on the jewels of the Spanish empire, the Viceroyalty of Upper Peru and New Spain (Mexico). 
1. One case is Armenians, who were the victims of genocide through a plan with different stages: disarmament, intellectual beheading, emasculation, and deportation. The arrival of Armenians in Latin America will be an issue of the negative agenda between Turkey and Latin America to this day.
For much of the 19th century we will attend wars of independence, civil wars, secessionisms and a "long wait" for the formation of modern states. It was only in the last quarter of a century, once consolidated and inserted into the model of capitalism of laissez-faire-laissez-passer as commodity exporting economies, only some of the Latin American states undertook formal contact with the Ottoman Empire.

During this period, the Ottoman Empire also undertook a number of reforms for example: "The reform of education that paved the way for European-style opening in engineering, military schools, public administration is the second stage of this important policy change. In addition, the Empire sent dozens of young students to be training programs in Western Europe to create a new generation of skilled civil bureaucrats for the state. Interestingly, the students returned with a liberal and critical thought of the Ottoman system, in addition, with the intention of carrying out a coup" (TURK, 2010, p. 3).

Undoubtedly, the profound changes that went through the empire were the economic ones, which impacted the social structure. The process of shifting from a traditional economy to a capitalism dependent on the export of raw materials was preceded by“"a long period (1792-1853) during which epidemics and wars, economic stagnation, and demographic decay had been the salient features of the Ottomans' world. The decrease in population, especially of Anatolia and Rumili, was so severe that the government sought to attract immigrants from Europe by offering incentives such as tax exemptions" (KARPAT, 1985:177).

The attraction of migrants from the Caucasus, the Balkans and Crimea to counteract the demographic decline led to a re-islamization of the empire's population to the detriment of the multinational and multiethnic nature of the empire. Until then, the legitimacy of the state was based on the idea of fair order and Islam was an important element in terms of regulating state affairs, however, the reforms introduced had other effects (TURK ,2010).

According to Karpat, the economic situation worsened: "Some other particular causes of economic dislocation for certain groups were the destruction of the major part of the vineyards by phylloxera; the opening of the Suez Canal, which caused the trade routes to shift southward; and the collapse of the silk industry due to a disease that killed the local worms over the period from 1875 to 1885 and made it necessary to buy silkworm eggs from France and ship the cocoons there" (KARPAT, 1985, p.178).

The consequence of all this led to the emigration of many citizens of the empire in search of better living conditions, which initiated an unthinkable bond until then with Latin America. Whether as Ottoman citizens or simply Turks, the arrival of different communities generated a diaspora that will turn its Ottoman identity to the Arab, Jewish, or Armenian thing with the future of time. ${ }^{1}$

After 1890 and during the Great War, the emigration of Ottoman communities to host countries in Latin America was the reason for the need for consular and diplomatic links. This explains the presence of the so-called "Turks" as colloquially called the citizens of the empire and which today constitute a considerable amount of the Latin American population. For example, Brazil has 9 million, Argentina 3.5 million, 
Venezuela 1.6million, Chile 1.1 million, Mexico 1.1 million and Colombia 800,000 descendants of immigrants who arrived in the new world (TASAM, 2016).

By virtue of the above, the macro-relationships were of a non-existent and sporadic nature. On the one hand, these focused on the immigration issues of the empire's citizens who came to the new world escaping the reality they were going through. On the other, trade flows were scarce despite the interest of deepening the link. Distance, communications, and language were made up of factors that hindered higher-level relationships.

This explains why only the visit of Emperor Peter of Brazil is recorded in 1871 and 1876 in a personal capacity and not on an official visit. More formal relations with the still Cuba under Spanish rule (with the opening of the Honorary Consulate of Havana in 1873) and with the two empires that existed in Latin America. On the one hand, Peter II of Brazil opened a Honorary Consulate in 1859 in Istanbul and on the other, Emperor Maximilian of Mexico sent a representative in 1864 to the Ottoman capital. At first, the relations were in consular nature with the aim of meeting the needs of the Ottoman citizens, despite being Syrians, Lebanese, Jews, Armenians, Palestinians, and Druze who would then stop using the name 'Ottoman'.

With Argentina, diplomatic relations began in 1909, demonstrating in the last years of the Ottoman Empire a certain degree of development. However, after the Great War, ties were resumed and formalized with the signing of the 1926 Treaty of Friendship (BOTTA, 2012). Then, Brazil and Mexico in 1927 and in 1928 respectively signed the Treaties of Friendship and Peace, thus initiating diplomatic relations with modern Turkey.

\section{The Republic of Turkev and Latin America until the end of the 20th century}

At the moment of opening the second capsule, the existence of a long period of duration can be identified, marked by the deepening of the geographical and diplomatic distance.This situation responded to the presence of exogenous conditions typical of the development of international politics as well as endogenous conditions inherent in each actor. For this reason, mutual irrelevance was the distinctive character of Turkish-Latin American relations during this period.

About exogenous conditions, it can be said that the interwar period was marked by three forms of penetration into the MENA under the auspices of League of Nations under the mandate regime, the protectorate and/or direct occupation. The end of the central empires also meant the end of the once enemy of the West and the crystallization of the territorial distribution project avoiding any kind of Turkish influence in the region.

Systemic changes explain the irrelevance in which the relations fell. On the one hand, the crisis of pure capitalism affected both actors, Latin America, and the Republic of Turkey, which until then had reached international insertion as commodity exporting countries. On the other hand, the attempts to channel the capitalist system had as a counter to the emergence of totalitarianisms in Europe and Asia, and with them, the sliding to World War II. 
To this end, the world was conditioned by the development of the Cold War, with a bipolar system, where both actors were under the umbrella of American influence. Turkey became NATO's southern flank, providing the second army in numerical terms and America Latina in the natural-influenced region of the United States. While both actors participated in the liberal order of the second post-war period (UN, IMF, WB, GATT) this did not result in a strategic rapprochement, on the contrary, the distances were greater. This was highlighted in the political dimension with the 1982 Falklands War, in which Turkey openly supported Britain as an ally within the framework of NATO.

As for endogenous conditions, Latin America in this period went through the economic dimension by a dislocation of the development model which led it to undertake a new one. The adoption of Industrialization by Import Substitution model allows to understand why the trade link with Turkey was not deepened. In the political dimension, the region went through the emergence of nationalist populism as well as institutional instability and the presence of coups, coupled with the emergence of armed left-wing movements in the 60s and 70s. In other words, there was a common denominator around national security for fear of red danger.

On Turkey's side, the war of independence spread until 1923 when the Republic was finally created, previously ending the sultanate in 1922 (and the caliphate in 1924). The country set out on the path of building a modern, secular, and nationalist state with the figure of the father of the homeland, Kemal Ataturk, who sought to give Turkey a new identity, far from the Ottoman past.

As Turk rightly holds up, "from then on the Turkish Republic began its ambitious project to cut the ties of a thousand years of its history, ideology and culture" (Turk, 2010, p. 5). For example, the new assembly raised that sovereignty came from the general will, including women with the right to vote; a new professional bureaucracy was established. Thus, nationalism has been applied to create a new modern nation and to replace the Ummah (Muslim community) through the assimilation of the practices of state institutions, the new elite aimed to create a "modern" nation and "a national identity" (CETIN, 2004, p.351).

To this end, and to modernize the state and provide it with a new identity, the capital was moved to Ankara. First, Islamic institutions were replaced by new Western and nationalists. Following this line, religious schools were closed, and education came under the jurisdiction of the new Ministry of Education. The Sharia Courts were also abolished and the constitutional status of Islam as the official religion of the Turkish people withdrew from the Constitution in 1928 (AHMAD, 1990; KARPAT, 1985;).

Second, Arabic writing was replaced by the Latin alphabet, with the purpose of cutting off society's relationship with its Islamic faith and The Ottoman past. In addition, legal figures such as marriage, divorce and inheritance laws were amended in accordance with European laws. As a result, the Swiss Civil Code was incorporated, along with the Italian Criminal Code and the German Trade Code in the second lustrum of the 20th.

As in Latin America, the military corporation was imbued with the power to defend the republic but was not a passive player in political life. 
The Turkish army dismissed democratically elected governments on no less than four occasions, two through coups in 1960 and 1980, and two others through the threat to the institutional break in 1971 and 1997, respectively. In other words, in Turkey the modernization project emerged as an elite project, designed, and imposed from above, as in many countries of the so-called Third World.

Regarding macro-relations, there was no density of issues on the external agenda between the two actors. Turkey as a kind of cyclops looked inward in order to consolidate the republic and the West to achieve state modernization and international integration. For its part, Latin America went through recurrent political and economic crises and prioritized the external relationship to the West, particularly the United States. This explains why only diplomatic relations were established with 7 Latin American countries (Argentina, Brazil, Chile, Peru, Cuba, Mexico, and Venezuela), without the presence of cultural and military attaches. It is worth mentioning that several Latin American countries related indirectly to Turkey for participating in Peacekeeping Operations in Cyprus. Highlighting the case of Uruguay, which became the first country in the region to recognize the Armenian genocide in 1965, which would be joined by other countries several decades later.

However, the presence of several extra factors historically affected mutual relationships. To the well-known distance, the language, the absence of cultural interactions, the meager levels of trade and the low direct external investment, was added to the absence of the proper Turkish diasporas until the arrival of the Gülen Movement in the 2000s (GONZÁLEZ LEVAGGI, 2012).

The first high-level visits were only in the 1990s. In this regard, the official visit of then-President Carlos Menem of Argentina in 1992 to Turkey and the tour of former Turkish President S. Demirel to Argentina, Brazil, and Chile in 1995 are highlighted. Since then, Turkey's Ministry of Foreign Affairs has begun to look more closely the region in terms of both diplomatic and trade relations. In 1998 Turkey raised the Plan of Action towards Latin America and the Caribbean, which ultimately failed because of the economic crises that were evident during 2000 and 2001 respectively at both latitudes.

Turkey's restoration as a re-emerging power and renewed ties with Latin America in the 21st century

At the time of opening the third capsule, and closer in time, it can be said that the 21st century witnessed profound changes in the reconfiguration and operation of the International Order. The relative loss of American power, the consolidation of an Asia-centric gravitational axis, and the challenge of the liberal order built in the second post-war period were added to the "rise of the rest" (ZAKARIA, 2004). In other words, the increasing spread of power was recognized in all its dimensions among the actors that make up the structure of the international system with the rise of the so-called emerging powers.

Despite theoretical discussions and a lack of conceptual univocity to denote what is meant as such, certain indicators have been used to ac- 
2. The Next Eleven group is estimated to be the next emerging powers of the 21st century: Bangladesh, Egypt, Indonesia, Iran, Mexico, South Korea, Nigeria, Pakistan, Vietnam, Turkey, and the Philippines.

3. The Economist Intelligence Unit named the group of Colombia, Indonesia, Vietnam, Egypt, Turkey, and Singapore with this new one, albeit with less marketing,

4. MIKTA is made up of Mexico, Indonesia, South Korea, Turkey, and Australia.

5. In the second decade of the 21st century, the factors that allowed countries to be renamed as emerging powers are tested in the economic dimension, which has already impacted some on the domestic political situation as in foreign policy actions. For example, China is experiencing a slowdown in its economic growth, with lower demand for commodities from the world - with the known impact on international prices - coupled with the trade war with the United States. Russia is another example of how the crisis particularly with Ukraine deepened the economic problems - coupled with the blockade by barely putting dependence on crude oil and gas exports at low international prices. Brazil, the Latin American giant that in the first decade of the 21st century presented itself as a power, not only went through an Orthodox economic adjustment - with strong social unrest - but also a political crisis and a right-wing turn of its government.

6. In the Turkish cosmogony, from the Ottoman imperial era to the present, there have been 4 restorations: the first has been Tanzimat - coinciding with the incorporation of the ideological legacy of the French Revolution only in 1839; the second has occurred with the establishment of the Republic after the First World War; the third with the adoption of the parliamentary system in the 1950s; and the fourth and last, with the implementation of a true multi-party system that allowed the AKP to come to power in 2002 count for this. For example, political stability - regardless of the type of regime implemented without respect for human rights - the model of development and sustained economic growth over time, and the design and implementation of an active but fundamentally assertive foreign policy in the regional and international context. Therefore, in this ascent, not only has the recognition of other international actors been important, but also of the "self-perception" that countries, including under that name, sought to project of themselves.

In this sense, when Goldman Sachs coined the acronym for BRICS (Brazil, Russia, India, China, and South Africa) he never thought about the popularity that this select group of countries would gain in political, academic and even international media circles. But this group did not reflect the true nature of an international system in full transformation. The performance achieved by other countries - according to the above-mentioned indicators - had allowed membership to be expanded by generating a large soup of letters when the Next ${ }^{2}$ Eleven, CIVETS ${ }^{3}$ or the recently named MIKTA appeared ${ }^{4}$ (SERBIN, 2017). In any of these three groups, a power synonymous with "model" for the region has been included, for holding the sixteenth position in the world economy, the sixth as a Member State associated with the European Union and for owning the second largest army within NATO, as is the case of the Republic of Turkey.

Beyond the privileged transcontinental geographical location thanks to the control of the Bosphorus Strait and the Dardanelles that separates 3\% of its European territory from the rest located on the Anatolian peninsula on the Asian continent - the weight of history - because it was a great empire that rivaled and cooperated alternately with the West - and to possess a unique identity, Turkey has entered the select concert of the emerging powers.

Among the reasons that lead to her identifying it there is the uniqueness of the "Turkish miracle", which is based on a triad that combines market economy, democracy and Islam - and which the West did not hesitate to support - which became a model of regional stability. However, like the rest of the emerging powers, favorable conditions in the second decade of the 21 st century have been reversed compared to the first, and Turkey has been no exception. ${ }^{5}$ This context, as can be analyzed, was marking international relations with Latin America.

Turkey's restoration as a re-emerging power had a starting point with the presence of endogenous conditions. In 2002 a new era was inaugurated in the institutional life of the country when the Islamic Justice and Development Party (AKP) first came to power by the hand of Recep Tayyip Erdogan, the then Prime Minister and currently strongman and President of the Republic. With the turn of the century behind a stage signified by the coups and trauma of the deep economic crisis of 2000 and 2001 when it sought to implement a model that combined national strategic interests with the vision of projecting the country to the world. Since then, it has coincided precisely with what the government has officially called Turkey's "restoration" with the "re-emerging" power projections in the international system. ${ }^{6}$ 
On the one hand, "restoration" alludes to the need to restore Turkey to lost status, knowing how to capture the "spirit of the times" to meet the challenges of a transforming global system. While it has not been the first restoration throughout its history, it is considered that the latter has given it its place in the world, combining in the country a new identity with a "strong democracy, a dynamic economy and an active foreign policy”(DAVUTOGLU, 2014).

These three elements coincide with the indicators mentioned $u t$ supra, also acquiring a specific meaning according to the official self-perception that during the first decade of AKP's rule raised in power. Turkey re-emerged from an imperial past with no territorial pretensions in line with the new international context and was called to play the role of regional and international power.

"Strong democracy" had to leave behind the stigma that a moderate religious party could not become in government under the parameters of a secular republic, as had been founded in 1923 by the "Father of the Homeland", Kemal Ataturk. Democracy had to be built on a multi-party system, regaining the "dignity" and "legitimacy" of the government with the vote of all citizens, exalting as the main value and bulwark of freedoms - political and civil - respect for the division of powers and the presence of strong institutions outside of all influence of the military corporation. The philosophical basis for the democratic system was the recovery of the citizen, assuring him the freedom to think, do and say without any prohibition. Thus, Turkey committed to "will maintain its position of being a state that contends with every kind of prohibition that restricts the freewill of humans" (DAVUTOGLU, 2014, p. 9). The moral basis of democracy should rest on the transparency and counterweights necessary to prevent excesses and corruption, for which institutional recasting was necessary.

The result has been the political stability that resulted in the AKP's tenure in government with 16 consecutive elections won at each of the levels of government for 17 years, demonstrating that democratic values were compatible with Islamic heritage - until then relegated. However, over time the criticism appeared when describing the new political system, because it was perceived as a government of "conservative democrats" (KARAVELI, 2017), which brought it closer to what the French thinker Alain Rouquié defined as "hegemonic democracy" (ROUQUIÉ, 2017). In other words, the presence of formal elections that in their operation is far removed from liberal democracy.

The "dynamic economy" was conceived as the main asset in which democracy as a political regime could respond to the needs of the population inward but also projected solidly to the world. In this sense, and against the current of Latin America in the new century, Turkey has opened its economy by pursuing neoliberal policies and an export oriented economic development model. This makes it possible to understand why the Turkish economic structure has similarities to that of developed countries, as the services sector has the greatest weight (58.2\%), followed by the industrial sector $(26.1 \%)$, the primary sector $(10.1 \%)$ - which has decreased its importance although it absorbs $30 \%$ of the labor force - and the construction sector (5.2\%) (WORLD BANK, 2014). 
7. A clear example of soft power exercised by Turkey have been the soap operas that were sold to differen Latin American countries showing the splendor of the then Ottoman Empire as well as the cultural richness of modern
Macroeconomic achievements during the first decade of the AKP government positioned Turkey as one of the fastest growing emerging economies. GDP has been multiplied 3.5 times; growth has been the average annual 5\%; inflation of $60 \%$ fell to a digit and unemployment fell to $9 \%$. The competitiveness of the Turkish economy allowed exports of medium-tech intermediate industrial goods to increase by positioning Turkish firms internationally and attracting, thanks to the good business climate, external direct investment (FDI) mainly from the European Union (EU).

The "active foreign policy" has been strategically designed to accompany the country's process of political and economic transformation. And this was structured on a theoretical corpus designed by those who were Foreign Minister and Prime Minister, Ahmet Davutoglu, which was called "Strategic Depth". By applying this doctrine, Turkey managed to enjoy unbeatable results in the international environment, more precisely in the nearby neighborhood.

Some of the principles formulated in foreign policy include the policy of zero problems with neighbors - which has involved looking back at the Middle East, a region to which it turned its back for decades, recomposing diplomatic ties in situ; multidimensionality - which has meant complementarity between new commitments, for example by intervening in the Israeli-Palestinian conflict by supporting the Arab cause, with the old alliances represented in NATO membership, without entering competition; autono$m y$ - understood as the ability to take action in areas of vital interest and in which it can collide with Western allies, as has been the attempt to mediate together with Brazil in the Iranian nuclear dossier; the multilateralism - by running for a multipolar world with active participation as a member in the multi-island spaces of the UN, NATO, the WTO, the G20, the Group of Friends of Syria, Iraq and Afghanistan; the de-securitization of foreign policy - which managed to restore the power of soft power history, culture and own resources over military reductionism in pursuit of building backed-up image of threatening and aggressive backgrounds; and rhythmic diplomacy - ready to act on the issues of the international agenda with a professional and renewed diplomatic corps with the opening of 30 new embassies in Africa, Latin America and Asia (BENLI ALTUNISIK, 2011).

Taken together, these principles catapulted Turkey into a position of power in the MENA region and, consequently, to occupy a privileged place in the concert of the nations. In this sense, the "Strategic Depth" had as its horizon the reintegration of the country into the international system, first using the region as a take-off platform for the global projection.

From these three aspects of "restoration," Turkey's self-perception has been that of a power that re-emerged from a high-powered past that once enjoyed. For this reason, Turkey has sought not to be seen as a mere bridge between the West and the East or a free rider in a convulsing region, but as a "central" power in the international system. In other words, it has adopted a "neo-Ottoman" revisionist vision without the pretenses of being an empire in traditional terms, combining hard power - economic and military performance - with soft power - in which ${ }^{7}$ it reconciled the Ottoman legacy and also the Sunni Islamic, a model for the Middle East region (DALACOURA, 2017). 
At the time of opening the third capsule of time in 2019, the changes were noticeable, especially in what it does to the density that macro-relationships acquired like never before seen in Turkish-Latin American relations. The new foreign policy designed in multidimensional terms allowed Turkey to establish renewed ties with the region over the past 10 years. Through intense communication and close cooperation with governments and other non-state actors, a strategic vision was raised in the title of the Expansion in Latin America and the Caribbean of Turkey. Thus, the Latin American region became vitally important, with its 605 million inhabitants and a GDP of more than \$6 trillion and 1.72 trillion foreign trade, rich natural resources, and emerging economy. Turkey’s total trade volume in the region has increased nine-fold and is still expanding compared to previous years.

Some initiatives, such as the 2006 Action Plan and the Declaration of The Year of Latin America and the Caribbean, at the same time indicated that Turkey's active foreign policy was beginning to deliver tangible results. The "Action Plan 2006 involved the Ministries of Economy, Industry and Trade of Latin American countries, as well as universities and business sectors that participated in meetings, congresses and seminars organized in order to deepen mutual knowledge and forge an agenda based on reciprocal interests.

To this end, it was a first step to achieve greater institutionalization of diplomatic relations with the countries of the region, which had been virtually inconsequential throughout the twentieth century. In this regard, Turkey initiated a process of rapprochement and negotiations to exchange political ideas with 14 of the most important countries in the region (Argentina, Bolivia, Brazil, Ecuador, Guatemala, Colombia, Costa Rica, Cuba, Mexico, Peru, Chile, Paraguay, Uruguay, Venezuela). In this line, new General Consulates were opened in Brazil and Colombia and the establishment of Trade Promotion Offices under the Ministries of Economy in Buenos Aires, Bogota, Caracas, Lima, Mexico DF, Santiago de Chile, and Havana was promoted. Undoubtedly, Brazil was the cornerstone of the relationship with the region, where progress was made in signing the Action Plan for a Strategic Partnership. In addition to the participation of other joint international initiatives, such as mediation in Iran's nuclear affair.

The strengthening of diplomatic relations was highlighted by President Erdogan's official visits in 2015 to Colombia, Cuba, and Mexico and in early 2016 Ecuador, Peru, and Chile. As a result of the July 2016 coup attempt in Turkey, the presidential tours in Latin America were interrupted but the region condemned the facts in solidarity with the Turkish people. For their part, Latin American representatives such as Luiz Inácio Lula Da Silva of Brazil, Hugo Chávez of Venezuela, Cristina Fernández de Kirchner of Argentina and Enrique Peña Nieto of Mexico paid out by diplomatic courtesy and interest the visits with tours that included Ankara.

A second step in relations was the Strategy for trade development with Latin American countries presented by the Turkish Ministry of Economy to conclude trade and economic agreements with the countries of the region. In this order, Trade and Economic Cooperation Agreements were concluded 
8. It is important to mention that the commercial volume in the first decade of the 21 st century increased considerably, especially given how meager it was during the previous period. Foreign trade made a significant leap from $\$ 2$ billion to $\$ 8$ billion in 2015, placing Brazil in the top spot followed by Mexico, Colom bia, Chile, and Argentina respectively.

9. In 2011, a free trade agreement was signed with Chile taking advantage of the previous agreement with the EU. with 13 countries (Argentina, Brazil, Ecuador, Guatemala, Guyana, Jamaica, Colombia, Cuba, Mexico, Paraguay, Peru, Chile and Uruguay) and follow-up mechanisms were established through the Joint Economic Commission ${ }^{8}$. Regarding free trade agreements, negotiations began - still ongoing - with the Caribbean Community (CARICOM), with the Central American Integration System (SICA) and the Southern Common Market (MERCOSUR). ${ }^{9}$

A higher density of issues appeared on the bilateral agenda, in a clear sign of entrenchment of mutual ties and interests. These include the elimination of the visa for Latin American citizens (except Cuba) and the establishment of daily flights with The Turkish Airlines company to the countries of the region.

However, a sensitive issue on the bilateral agenda has remained generating diplomatic frictions, which revolves around the recognition of the Armenian genocide. In chronological order, Venezuela on 14 July 2005 condemned the genocide and supported the historical claims made by the Armenian people; Argentina, with 135 thousand descendants of Armenians, sanctioned 2007 Law 26.199 of "Declaration of 24 April Day of Action for Tolerance and Respect among Peoples"; Bolivia officially expressed its appreciation with Declaration No.122/2015; Brazil on 2 June 2015 issued the Federal Senate resolution under No. 550/2015 recognizing the genocide of the Armenian people; and Paraguay on 29 October 2015 unanimously passed the law of the official recognition of the genocide perpetrated against the Armenian people. (TASAM, 2018).

The MERCOSUR Parliament also adopted resolution 04/2007 at its plenary meeting on 19 November 2007 in which it publicly acknowledges the genocide on the Armenian people. For its part, the Latin American Parliament composed of National Congresses and Assemblies throughout Latin America passed on July 31, 2015, coinciding with the commemoration of the hundredth anniversary of the Armenian genocide, a draft resolution officially recognizing the issue.

\section{Conclusions}

Under the analysis carried out, it can be said that Turkish-Latin American relations are long-standing and state-conditioned by the presence of exogenous and endogenous factors over time. This article sought to reconstruct the context of these relationships using the timeframe of the Time Capsules. Thus, with each of the openings, the information obtained was valuable for the analysis of the three contexts in which macro-relations were developed at both latitudes.

With the opening of the first capsule we can conclude that during the existence of the Ottoman Empire and the Spanish Empire relations were non-existent, even ignoring each other. This responded to the non-collision interests pursued by each actor in the international system. On the one hand the Ottoman Empire spread throughout Central and Eastern Europe, becoming a large multi-ethnic and multinational political unit whose main threat was the Empire of Tsars. On the other hand, the main concern of the Spanish empire was to maintain control and administration in its former colonies in the new world, far from the meddling of western European powers. 
It was only at the end of the 19th century, when the so-called 'Sick Man of Europe' was losing territories, coupled with economic crises - and its well-known social effects - Ottoman relations with Latin America were established by the issue of immigration. The arrival of the so-called 'Turks' and their situation in the countries was the pretext for establishing consular relations. However, it was after the Great War and once the Republic of Turkey was created in 1923 that diplomatic relations with Latin American countries were formalized.

The opening of the second capsule of time at the end of the twentieth century allowed us to understand how endogenous and exogenous factors conditioned Turkish-Latin American relations, reaching the point of irrelevance. On the one hand, Turkey had to rebuild its secular and national identity with an eye on Europe and Latin American countries to overcome recurrent political and economic crises.

While both actors were participating in the same bloc during the Cold War, international relations were formal and conducted through the bureaucratic way of the respective chancelleries. It was only at the end of the 20th century that there were official visits and attempts to channel relations, which failed because of the economic crises of 2000 and 2001.

The opening context of the third Time Capsule in 2019 exposed an intensification of Ties between Turkey and Latin America. In the 21st century, changes in the international order coupled with internal changes in each of the actors led to an approach like never before. Turkey was not only recognized as an emerging power at the international level, but it also self-perceived as a central power in international affairs that reemerged from a glorious past. In this sense, the design of a new multidimensional foreign policy allows us to understand how it sought to approach Latin America with diplomatic initiatives and strategic projects of regional cooperation and integration. Ankara's diplomacy clearly found in the region the political conditions for rapprochement, ideological harmony - with the presence of the so-called Latin American left turn - and the search for membership of the Global South made it possible to strengthen ties and shorten the distances that had separated them for years.

However, it cannot be overlooked that in the second decade of the 21 st century that approach began to lose intensity. Changes in governments with different political signs in Latin America, new economic crises, as well as the so-called authoritarian drift in which Turkey plunged after the 2016 coup attempt, helped to slow international ties.

In other words, when a new Time Capsule is opened in the future, we will be able to reconstruct a new context, and thus learn how the challenges and opportunities that are present in Turkey's international relations with Latin America were managed.

\section{References}

AHMAD, F. The Making of Modem Turkey. Routledge London and New York, 1990.

BENLI ALATUNISIK, M. La política exterior de Turquía en el siglo XXI, Anuario Internacional CIDOB, Barcelona, p.421-426, 2011.

BOTTA, P. Las relaciones diplomáticas y consulares entre la República Argentina y el Imperio Otomano. Publicado por jprbotta2791, 2012. Disponible en: https://es.scribd.com/doc/.../ Argentina-y-El-Imperio-Otomano. 
CETIN, M. Z. Tales of Past, Present, and Future: Mythmaking and Nationalist Discourse in Turkish Politics, Journal of Muslim Minority Affairs, v. 24, n. 2, p. 347-365, 2004.

DALACOURA, K. A new phase in Turkish Foreign Policy, MENARA, n. 4, February, p. 1-6, 2017.

DAVUTOGLU, A. The Restoration of Turkey: Strong Democracy, Dynamic Economy, and Active Diplomacy; SAM Centre for Strategic Research, n. 7, p. 1-22, agosto 2014.

EQUILIBRIUM GLOBAL. Entrevista a Mehmet Necati Kutlu, 21 de mayo 2018. Disponible en: https://equilibriumglobal.com/entrevista-a-mehmet-necati-kutlu-universidad-ankara/.

ESCUDE, C. La política exterior de Menem y su sustento teórico implícito, en América Latina/ Internacional, Bs.As. v. 8, n.27, p. 394-406, 1991.

GONZALEZ LEVAGgi, A. América Latina y Caribe, la última frontera de la "Nueva" Política Exterior de Turquía, Araucaria. Revista Iberoamericana de Filosofía, Política y Humanidades, año 14, n. 28, pp. 179-202, 2012.

KARAVELI, H. Turkey's Authoritarian Legacy. The Cairo Review, spring, p. 62-71, 2017.

KARPAT, K. The Ottoman emigration to America 1860-1890, Middle East Studies, USA, n. 17, p. 175-209, 1985.

ROUQUIE, A. El siglo de Perón. Ensayo sobre las democracias hegemónicas, Buenos Aires, Edhasa, 2017.

SERBIN, A. ¿Un triángulo escaleno? América Latina y el Caribe, China y los Estados Unidos y las narrativas del nuevo ciclo, Anuario de Integración, n.13, p. 31-58, 2016.

TASAM Tercer Congreso Turco-Latinoamericano y Caribeño. Cooperación Estratégica y los Turcos, Turkish Asian Center for Strategic Studies, Estambul, p. 1-12, 2016.

TURK, H. Turquía en el siglo XXI: ¿un aumento de poder en la periferia?, Pensamiento y Poder, Colombia, v.1, n. 5, p. 67-91, 2010.

VALLEJO FERNANDEZ CELA, S. La Caída del Imperio Otomano y la fundación de la República Turca: Una visión española, Cuadernos de Historia de las Relaciones Internacionales II, Madrid, n. 2, p. 11-38, 2001.

WORLD BANK Turkey's transitions: integration, inclusion, institutions. New York: World Bank, December 2014. Disponible en: http://www.worldbank.org/en/country/turkey/publication/turkeys-transitionsintegration-

ZACARIA, F. The Post-american World. Espasa Libros, España, 2004. 